\title{
Exacerbation of experimental autoimmune encephalomyelitis in mice deficient for DCIR, an inhibitory C-type lectin receptor
}

\author{
Akimasa SENO ${ }^{1-3)}$, Takumi MARUHASHI ${ }^{1,2)}$, Tomonori KAIFU ${ }^{1,2,4)}$, Rikio YABE ${ }^{1,2)}$, \\ Noriyuki FUJIKADO ${ }^{1)}$, Guangyu MA ${ }^{1)}$, Tetsuro IKARASHI ${ }^{5)}$, Shigeru KAKUTA ${ }^{5)}$, and \\ Yoichiro IWAKURA ${ }^{1-4,6)}$ \\ 1) Center for Experimental Medicine and Systems Biology, The Institute of Medical Science, The University of Tokyo, \\ 4-6-1 Shirokanedai, Minato-ku, Tokyo 108-8639, Japan \\ ${ }^{2)}$ Center for Animal Disease Models, Research Institute for Biomedical Sciences, Tokyo University of Science, \\ Noda-shi, Chiba 278-0022, Japan \\ 3) Department of Computational Biology, Graduate School of Frontier Sciences, The University of Tokyo, Kashiwa- \\ shi, Chiba 277-0882, Japan \\ 4) Core Research for Evolutional Science and Technology (CREST), Japan Science and Technology Agency, \\ Kawaguchi-shi, Saitama 332-0012, Japan \\ ${ }^{5)}$ Department of Biomedical Science, Graduate School of Agricultural and Life Sciences, The University of Tokyo, \\ Bunkyo-ku, Tokyo 113-8657, Japan \\ ${ }^{6)}$ Medical Mycology Research Center, Chiba University, Chuo-ku, Chiba 250-8673, Japan
}

\begin{abstract}
Dendritic cell immunoreceptor (DCIR) is a C-type lectin receptor containing a carbohydrate recognition domain in its extracellular portion and an immunoreceptor tyrosine-based inhibitory motif, which transduces negative signals into cells, in its cytoplasmic portion. Previously, we showed that $\mathrm{Dcir}^{-1}$ mice spontaneously develop autoimmune diseases such as enthesitis and sialadenitis due to excess expansion of dendritic cells (DCs), suggesting that DCIR is critically important for the homeostasis of the immune system. In this report, we analyzed the role of DCIR in the development of experimental autoimmune encephalomyelitis (EAE), an autoimmune disease model for multiple sclerosis. We found that EAE was exacerbated in $\mathrm{Dcir}^{-1}$ mice associated with severe demyelination of the spinal cords. The number of infiltrated $C D 11 c^{+} \mathrm{DCs}$ and $\mathrm{CD} 4^{+} \mathrm{T}$ cells into spinal cords was increased in $\mathrm{Dcir}{ }^{--}$mice. Recall proliferative response of lymph node cells was higher in $\mathrm{Dcir}^{-1}$ mice compared with wild-type mice. These observations suggest that DCIR is an important negative regulator of the immune system, and $D \mathrm{cir}^{-}$- mice should be useful for analyzing the roles of DCIR in an array of autoimmune diseases.
\end{abstract}

Key words: C-type lectin receptor, dendritic cell immunoreceptor, experimental autoimmune encephalomyelitis, multiple sclerosis

\section{Introduction}

Multiple sclerosis (MS) is an autoimmune inflammatory disease, in which myelin sheath surrounding the axon of a nerve cell is damaged, eventually causing neurological disorders, such as diplopia, bladder dysfunction, tremor and ataxia [7]. Experimental autoimmune encephalomyelitis (EAE) is the most popular ani-

(Received 12 September 2014 / Accepted 13 October 2014 / Published online in J-STAGE 15 December 2014)

Address corresponding: Y. Iwakura, Center for Animal Disease Models, Research Institute for Biomedical Sciences, Tokyo University of Science,

2641 Yamazaki, Noda, Chiba 278-0022, Japan

Supplementary table and figures: refer to J-STAGE: https://www.jstage.jst.go.jp/browse/expanim

(C)2015 Japanese Association for Laboratory Animal Science 
mal model for MS, in which mice are immunized with myelin oligodendrocyte glycoprotein (MOG) as an autoreactive antigen. T cell infiltration into the spinal cords and pro-inflammatory cytokine production from the infiltrated cells are pathogenic for the development of EAE [14]. Both Th17 cells, which secrete IL-17, and Th1 cells, which produce Interferon(IFN)- $\gamma$, are detected in the affected spinal cords [39]. However, the pathogenic roles of IFN- $\gamma$ are controversial. Peripheral administration of IFN- $\gamma$ had no effect on the development of EAE, whereas intraventricular administration of IFN- $\gamma$ alleviated or resolved the neurological deficits $[3,12,43]$. Thus, Th1 cells are dispensable, or rather beneficial, for the development of EAE. On the other hand, IL-17 is crucial for the development of encephalomyelitis; the development of EAE is significantly suppressed in $I l 17^{-/}$mice [20]. IL-23 is an important cytokine which induces naive T cells to differentiate Th17 cells. Il $23 a^{-/}$mice do not develop EAE and IL-23 deficient T cells are less encephalitogenic than wild-type (WT) T cells [21, 41]. Granulocyte-macrophage colony-stimulating factor (GM-CSF), which stimulates dendritic cells (DCs) to secret IL-23, is also pathogenic in EAE [9]. Thus, encephalitogenic Th17 cells play crucial roles in the development of EAE. However, the mechanism how Th17 cell differentiation is controlled is largely unknown.

DCs play an important role in the development of EAE as the antigen presenting cells to encephalitogenic $\mathrm{T}$ cells [15]. DCs present antigens from pathogens as well as from self to activate the acquired immune system. Furthermore, DCs sense pathogens by an array of innate immune receptors by recognizing pathogen associated molecular patterns such as glycoproteins, lipoproteins, and polysaccharides, which are exposed on the surface of pathogens, causing induction of cytokines and pathogen-specific T cell polarization [19, 31]. Innate immune receptor-mediated signalings are also important for the development of EAE [27]. C-type lectin receptors (CLRs) are one of such receptors [34] and regulate T cell responses in EAE [1, 15, 30, 45]. However, the regulatory mechanisms involving CLRs have not been elucidated yet.

Dendritic cell immunoreceptor (DCIR; also named C-type lectin domain family 4 member a2 (Clec4a2) and C-type lectin super family 6 (Clecsf6)) is a CLR family protein, which contains carbohydrate recognition domain in the extracellular part and the immunoreceptor tyrosine-based inhibitory motif (ITIM) in the cytoplasmic region [2]. Because ITIM transduces negative signaling, DCIR is implicated in the suppression of cell function upon recognition of the ligands [11, 32, 33]. Previously, we found that Dcir is expressed in DCs and macrophages and the expression is greatly enhanced in the joints of rheumatoid arthritis models such as HTLV-I transgenic mice and IL-1 receptor antagonist deficient mice [10]. We showed that aged DCIR deficient $\left(\right.$ Dcir $\left.^{--}\right)$mice spontaneously developed sialadenitis and enthesitis, associated with elevated serum autoantibodies and DC expansion [11]. Moreover, $\mathrm{Dcir}^{-/}$mice were more sensitive to collagen-induced arthritis, with elevated collagen-specific $\mathrm{T}$ cell responses, augmented antibody production against type II collagen, and expansion of DC population. We showed that DC expansion was caused by the deficiency of DCIR, because DCIR regulated the differentiation and proliferation of DCs by suppressing GM-CSF signaling through the inhibition of signal transducer and activator of transcription 5 phosphorylation [11]. These findings indicate that DCIR is an important regulator of the immune system by regulating the physiological levels of DCs in vivo and suggest that DCIR may be involved not only in the development of autoimmune arthritis but also in a wide range of autoimmune diseases.

To examine this possibility, we have analyzed the effects of DCIR deficiency on the development of EAE using $\mathrm{Dcir}^{-1}$ mice. We showed that the development of EAE was exacerbated in $\mathrm{Dcir}^{-/}$mice, with higher incidence, earlier onset, and severer symptoms than in WT mice. Histological analyses showed enhanced inflammation in the spinal cords of $\mathrm{Dcir}^{-/}$mice, where inflammatory score and demyelination of the nerves in the white matter were increased compared to those of WT mice. Infiltration of immune cells including $\mathrm{CD}^{+} \mathrm{T}$ cells and $\mathrm{CD} 11 \mathrm{c}^{+}$DCs into the spinal cord was greatly increased in $\mathrm{Dcir}^{--}$mice at the late phase of EAE. Moreover, recall $\mathrm{T}$ cell proliferative response of $\mathrm{Dcir}^{-/}$mice against $\mathrm{MOG}_{35-55}$ peptide was higher than that of WT mice. These results clearly demonstrate that DCIR plays an important role in the development of EAE.

\section{Materials and Methods}

\section{Mice}

$\mathrm{Dcir}^{-1}$ mice [11] were backcrossed to C57BL/6J (Japan SLC, Japan) over twelve generations. Age- and gender-matched WT C57BL/6J mice were purchased 
from Japan SLC. All mice were kept under specific pathogen-free conditions in environmentally controlled clean rooms at the Center for Experimental Medicine and Systems Biology, the Institute of Medical Science, the University of Tokyo, and Research Institute for Biomedical Sciences, Tokyo University of Science. All animal experiments were approved by the committees for animal experiments of both universities and conducted according to the institutional ethical guidelines for animal experiments and the safety guidelines for gene manipulation experiments.

\section{Induction and evaluation of EAE}

Progressive EAE was induced in WT and $\mathrm{Dcir}^{-/}$mice by subcutaneous immunization with $300 \mu \mathrm{g}$ of $\mathrm{MOG}_{35-55}$ peptide (MEVGWYRSPFSRVVHLYRNGK) emulsified in $100 \mu \mathrm{l}$ of incomplete Freund's adjuvant (IFA) (Thermo Scientific, USA) and PBS (1:1) supplemented with $500 \mu \mathrm{g}$ non-viable Mycobacterium Tuberculosis H37RA (Difco Laboratories Inc., USA) on day 0 and $7 . \mathrm{MOG}_{35-}$ ${ }_{55}$ peptide was synthesized by solid-phase synthesizing methods and purified by HPLC by Prof. Ohmi (The Institute of Medical Science, The University of Tokyo, Japan). We judged the development of EAE by macroscopic evaluation. The clinical scores were graded as follows: 0 , no disease; 1 , limp tail; 2 , hind limb weakness; 3 , hind limb paralysis; 4 , hind and fore limb paralysis and 5 , moribund state. The mean clinical score was calculated by averaging the scores of all the mice in each group, including animals that seemingly did not develop EAE. Cumulative disease score is the sum of daily clinical scores of each individual mouse during the observation period and reported as an average within each group.

\section{Histological analysis}

At day 30 after immunization, mice were anesthetized with avertin (Sigma-Aldrich, USA) and perfused with PBS to rinse blood off from the spinal cords through the intracardiac route using a peristaltic pump set (ATTO, Japan) at a flow rate of $2 \mathrm{ml} / \mathrm{min}$, followed by perfusion with $10 \%$ formalin neutral buffer solution, $\mathrm{pH}$ 7.4. Spinal cords, which were embedded in paraffin (Sakura Finetek, Japan) using Tissue-Tek (Sakura Finetek), were cross-sectioned at the between L3 and L5 level with 6 $\mu \mathrm{m}$ thickness, using a tissue microtome (BIOCUT microtome; Leica, Germany, or Sledge Microtome IVS410; Sakura Finetek). Serial sections were stained with hematoxylin and eosin (H\&E) (Sigma-Aldrich) or luxol fast blue (LFB) (Nacalai Tesque, Inc., Japan, or MUTO pure chemicals Co., LTD., Japan). Images were taken using a microscope (CKX41; OLYMPUS, Japan) with a camera (DP21; OLYMPUS). The inflammation conditions were evaluated using at least three tissue sections of the lumber spinal cord per mouse, followed by the instructions described below. We determined inflammation scores as follows: 0 , no inflammation; 1 , cellular infiltration only in the perivascular areas and meninges; 2, mild cellular infiltration (less than one third part of the white matter is infiltrated with inflammatory cells); 3 , moderate cellular infiltration (more than one third part of the white matter is infiltrated with inflammatory cells); and 4 , infiltration of inflammatory cells are observed in the whole white matter [25, 37]. We calculated demyelination as follows; pictures of the spinal cord were taken after LFB staining, the demyelinated area was determined with ImageJ software (National Institutes of Health, USA) and the ratio of demyelinated area/total area was calculated.

Measurement of anti-MOG ${ }_{35-55}$ antibody titers in serum

The titer of anti-MOG $\mathrm{MO}_{35-55}$ antibodies was detected by ELISA as described $[28,35]$, with the following modifications. Briefly, $\mathrm{MOG}_{35-55}$ peptide ( $3 \mu \mathrm{g}$ per well) were coated on 96-well plates by incubating at $4^{\circ} \mathrm{C}$ overnight. After substantial washing with PBS, $30 \mu 1$ of 100 -fold diluted sera was incubated in duplicates for $1 \mathrm{~h}$ at room temperature. After washing, alkaline phosphatase-labeled goat anti-mouse Igs (ZYMED, USA) were reacted for $1 \mathrm{~h}$ at room temperature, followed by the addition of $p$-nitrophenyl phosphate substrate (Sigma-Aldrich). The titer of anti-MOG $\mathrm{MO}_{35-55}$ antibody was given as an absorbancy value at $415 \mathrm{~nm}$.

Purification of lymphocytes in lymph nodes and infiltrated cells in the spinal cords

EAE-induced mice were anesthetized with avertin and perfused with PBS. Then, brachial and axillary lymph nodes (LNs) were collected and pooled. The entire spinal column was removed by gross dissection and spinal cords were ejected by a flush with a syringe attached in an 18-gauge needle. The LNs and spinal cords were incubated in $200 \mathrm{U} / \mathrm{ml}$ collagenase from Clostridium histolyticum (Sigma-Aldrich) in HBSS for $30 \mathrm{~min}$ at $37^{\circ} \mathrm{C}$ separately. Then, meshed lymphocytes were counted and analyzed. The cell suspension of dissociated spinal cord 
tissue in 30\% Percoll (Sigma-Aldrich) was overlaid on a $70 \%$ Percoll in a $15 \mathrm{ml}$ polypropylene tube and centrifuged at 2,200 rpm for $20 \mathrm{~min}$ at room temperature. Cells were collected from the interface between 30 and $70 \%$ Percoll.

\section{Flow cytometric analysis}

Whole spinal cord infiltrated cells or $2.0 \times 10^{5}$ lymphocytes were stained with $2 \mu \mathrm{g} / \mathrm{ml}$ monoclonal antibodies (mAbs) after Fc $\gamma$ receptor blocking with 2.4G2 Ab. After cell surface staining, cells were fixed with $4 \%$ paraformaldehyde and permeabilized with $0.1 \%$ saponin, and then intracellular staining was performed. Anti-mouse CD11c (N418 or HL3), CD4 (RM4-5 or GK1.5), CD8 (53-6.7), CD40 (3/2, 3), CD80 (16-10A1), CD86 (GL-1), major histocompatibility complex class II (MHC class II) (M5/114.15.2), granulocyte-differentiation antigen-1 (Gr-1) (RB6-8C5), IFN- $\gamma$ (XMG1.2) and IL-17A (TC1118H10.1) were purchased from Biolegend (USA). Phcoerythrin (PE)-conjugated IL-17A (TC11-18H10) and biotin-conjugated anti-mouse OX40 ligand (OX40L) (RM134L) were purchased from BD Pharmingen (USA). $\mathrm{PE} / \mathrm{Cy} 7$-conjugated streptavidin was purchased from $\mathrm{BD}$ Bioscience (USA). Stained cells were detected with a FACSCanto II Flow Cytometer (Becton, Dickinson and Company, USA) and analyzed with BD FACS Diva (Becton, Dickinson and Company) and FlowJo software (Tree Star, USA). Dead cells which stained by 7-Amino Actinomycin D (7-AAD) were excluded.

\section{$M O G_{35-55}$-specific $T$ cell proliferation}

WT and $D \mathrm{cir}^{--}$mice were subcutaneously immunized with $100 \mu \mathrm{g}$ of $\mathrm{MOG}_{35-55}$ peptide emulsified in $100 \mu \mathrm{l}$ of IFA (Thermo Scientific) and PBS (1:1) supplemented with $250 \mu \mathrm{g}$ Mycobacterium Tuberculosis H37RA (Difco Laboratories Inc.) on day 0 . They were intraperitoneally administrated with $200 \mu \mathrm{g}$ of pertussis toxin (List Biological Labs, Inc., USA) in $100 \mu 1$ PBS on day 0 and 2. Brachial and axillary LN cells were harvested at day 7 after immunization and cultured at $3 \times 10^{5}$ cells/well in 96-well culture plates with or without $\mathrm{MOG}_{35-55}$ for 3 days. $\left[{ }^{3} \mathrm{H}\right] \mathrm{TdR}(0.25 \mu \mathrm{Ci} / \mathrm{ml})$ was incorporated for the last $6 \mathrm{hr}$ and the radioactivity was measured with a MicroBeta (PerkinElmer, Inc., USA).

\section{Statistical Analysis}

We used the Student's $t$-test for statistical evaluation of all results except for the EAE cumulative incidence
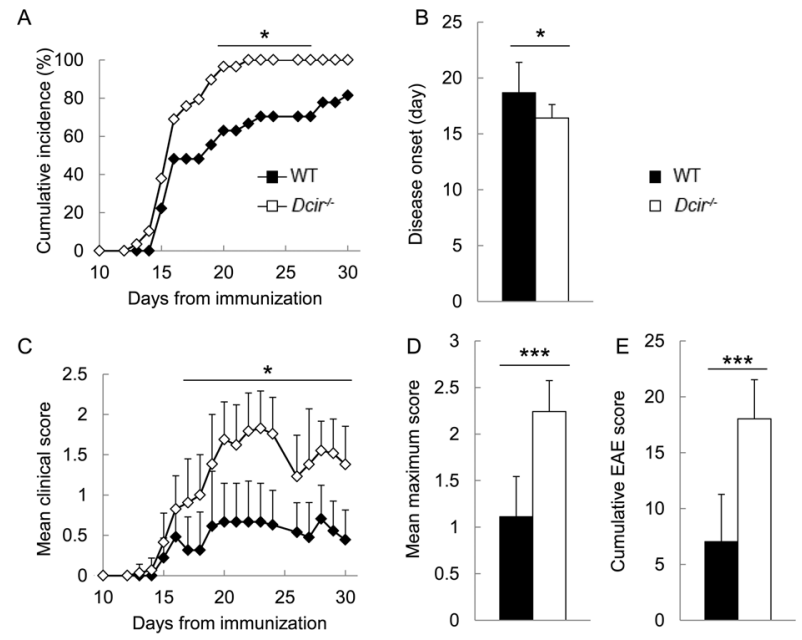

Fig. 1. The development of EAE is exacerbated in $\mathrm{Dcir}^{-1-}$ mice. WT and $\mathrm{Dcir}^{-/-}$mice were immunized subcutaneously with $\mathrm{MOG}_{35-55}$ peptide emulsified in CFA, and the development of neurological symptoms was monitored for 30 days. (A) Cumulative incidence of EAE. (B) The average days of EAE onset among EAE developed mice in each group. (C) Mean EAE clinical score. (D) Mean maximum score in each mouse group. (E) Cumulative EAE scores in WT and $\mathrm{Dcir}^{-1-}$ mice over the course of the experiment. The data show combined results of three independent experiments with 5-16 mice for each group (individual data are shown in Supplementary Fig. 1 and Supplementary Table 1). Total number of mice examined was 27 for WT mice and 29 for $\mathrm{Dcir}^{-1-}$ mice. Data are expressed as the means + SEM for each group. ${ }^{*} P<0.05$ and ${ }^{* * *} P<0.005$ vs. WT mouse score.

and clinical score; they were evaluated by chi-square test and the Mann-Whitney U-test, respectively.

\section{Results}

$D C I R^{-/}$mice develop severer EAE compared to wildtype mice

To investigate the pathological role of DCIR in EAE, we monitored the development of clinical signs of EAE in $\mathrm{Dcir}^{-/}$mice after immunization with $\mathrm{MOG}_{35-55}$. Under our experimental conditions, two-third of WT mice developed EAE. By contrast, all the $\mathrm{Dcir}^{-/}$mice developed EAE (Fig. 1A, individual data are shown in Supplementary Fig. 1 and Supplementary Table 1) and the onset of the disease in $\mathrm{Dcir}^{-/}$mice was earlier than that of WT mice (Dcir--; $16.4 \pm 1.2$, WT; $18.7 \pm 2.7,{ }^{*} P<$ $0.05)$ (Fig. 1B). Also, the clinical score of $\mathrm{Dcir}^{-/-}$mice $(1.83 \pm 0.46$ at 23 days $)$ was severer than that of WT mice $(0.67 \pm 0.48$ at 23 days, $* P<0.05)$ (Fig. 1 C), and 


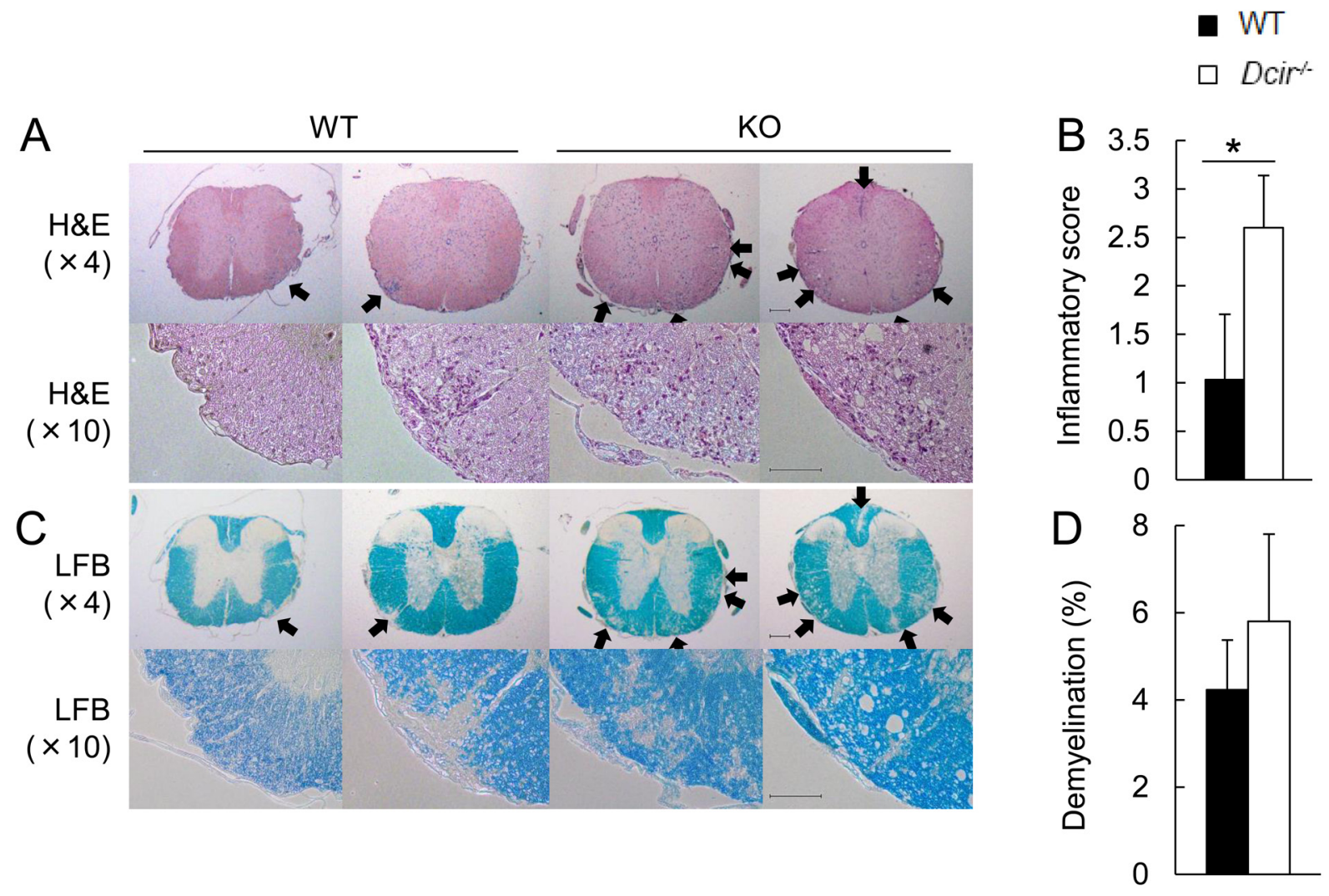

Fig. 2. Histopathological examination of the EAE-developed spinal cords. (A) At day 30 after immunization, tissue sections of the spinal cords were stained with H\&E. (B) Histological scores (inflammatory score) of the inflammatory lesions. (C) LFBstained serial sections of (A). Their inflammatory scores are; WT $=1$, and $\mathrm{Dcir}^{-/}=2$. (D) Demyelination was calculated with the LFB-stained sections. Representative sections depicting inflammation and demyelination in the lumbar spinal cords of EAE mice. Arrows indicate infiltration of inflammatory cells in (A) and demyelination of the nerves in (C), and expanded pictures of anterior nerve-root are shown in lower panels. The percentage of demyelinated area was calculated as described in materials and methods. Quantitative results were obtained at least three sections per mouse from five mice in each group. The data are representative of two independent experiments with similar results. Their EAE clinical scores at day 30 were; WT $=0$ or $1, \mathrm{Dcir}^{-1-}=1$ to 3 . We used the same or serial sections. Scale bar: $200 \mu \mathrm{m}$. Each graph represents as the mean + SD. ${ }^{*} P<0.05$ vs. WT mouse score.

the maximum score of the symptoms was higher $\left(\mathrm{Dcir}^{-/}\right.$; $2.24 \pm 0.33$, WT; $1.11 \pm 0.43, * * * P<0.005$ ) (Fig. 1D). The cumulative disease score during day 10 to 30 was also higher in $\mathrm{Dcir}^{--}$mice $\left(\mathrm{Dcir}^{-/} ; 18.0 \pm 3.5\right.$, WT; 7.0 $\pm 4.2, * * * P<0.005$ ) (Fig. 1E).

Next, histopathology was examined in these mice. To examine the degrees of infiltration of immune cells in the spinal cords, a series of tissue sections of inflamed spinal cords at the lumber level from EAE-induced mice were stained with H\&E (Fig. 2A). H\&E staining showed that the infiltration of mononuclear cells and polymorphonuclear leukocytes into the spinal was observed at widespread area and inflammatory score was increased in $\mathrm{Dcir}^{-/}$mice compared with WT mice (Figs. 2A and B). Furthermore, LFB staining displayed that demyelin- ation, which corresponds to weaker stain at anterior and lateral funiculus (arrowheads indicated the sites of demyelination) of the nerves in the white matter, was enhanced in $\mathrm{Dcir}^{-/}$mice compared with WT mice, (Fig. $2 \mathrm{C}$ and $\mathrm{D})$. These demyelinated nerves were observed at the same site of inflammation (Figs. 2A and C). Furthermore, $\mathrm{Gr}-1^{+}$cell infiltration into spinal cord tended to be increased in $\mathrm{Dcir}^{-/}$mice at day 28 after immunization (Supplementary Fig. 2). Therefore, the severe paralysis seen in $\mathrm{Dcir}^{-/}$mice is correlated with significant increases of inflammation and demyelination of the spinal cord. These results indicate that $\mathrm{Dcir}^{-/}$mice are highly susceptible to the development of EAE, suggesting that DCIR negatively regulates the development of EAE. 

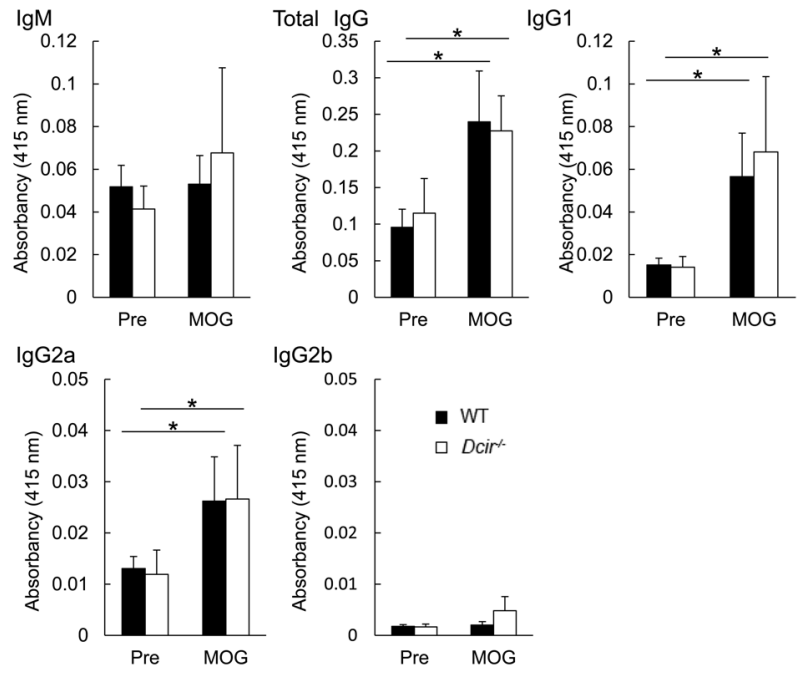

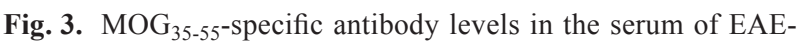
induced mice are similar between WT and $\mathrm{Dcir}^{-1-}$ mice. Sera (WT, Dcir ${ }^{-1}: \mathrm{n}=8$ each) were collected at 20 days after immunization, and the levels of $\mathrm{MOG}_{35-55}$-specific antibodies were determined by ELISA. The data are expressed as means $+\mathrm{SD}$, and are representative of two independent experiments. ${ }^{*} P<0.05$ vs. WT mouse score.

As autoreactive antibodies were detected in sera of MS patients [46] and antibodies specific to $\mathrm{MOG}_{35-55}$ can amplify inflammation and demyelination in the central nervous system $[24,26]$, we measured the titer of $\mathrm{MOG}_{35-55}$-specific antibodies in the serum of immunized mice. The IgM-type anti-MOG $35-55$ antibodies did not significantly change in the serum. Antibody levels of the IgG1 and IgG2a subtype against $\mathrm{MOG}_{35-55}$ were increased after immunization with $\mathrm{MOG}_{35-55}$, but that of the IgG2b subtype was not increased (Fig. 3). However, no difference of antibody levels of these subtypes or total IgG was observed between $\mathrm{Dcir}^{-/}$mice and WT mice, suggesting that DCIR is dispensable for the production of autoantibodies.

\section{Infiltration of $C D 11 c^{+}$cells and $C D 4^{+} T$ cells into the} spinal cord is increased in Dcir-- mice

Autoreactive T cells play an important role in the development of EAE. We found that infiltration of $\mathrm{CD}^{+}$ and $\mathrm{CD} 11 \mathrm{c}^{+}$cells in the spinal cord was significantly increased in $\mathrm{Dcir}^{--}$mice at 20 days after immunization, when the clinical score of $\mathrm{Dcir}^{-/}$mice was significantly higher than that of WT mice (Figs. 4A and B). $\mathrm{CD}^{+}$and $\mathrm{CD} 11 \mathrm{c}^{+}$cells in the draining LNs were also increased in $\mathrm{Dcir}^{--}$mice (Figs. 4C and D). The proportion of $\mathrm{CD} 4^{+}$ $\mathrm{T}$ cells was significantly increased in the LNs of $\mathrm{DCir}^{-/}$
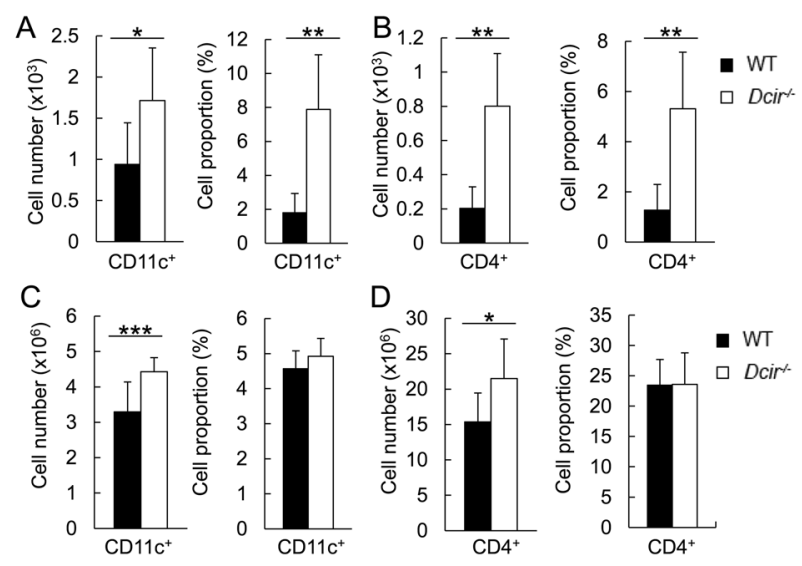

Fig. 4. The numbers and proportions of infiltrated cells in the whole spinal cord (A, B) and in lymph nodes (LNs) (C, D) are increased in $\mathrm{Dcir}^{-1-}$ mice. At 20 days after immunization, single cell suspensions were prepared from the spinal cords and LNs. Cells were analyzed by flow cytometry after staining with antibodies against indicated antigens. The data are expressed as means $+\mathrm{SD}$, and are combined results of two independent experiments (A, B; WT, Dcir ${ }^{-1-}: \mathrm{n}=6$ each, C, D; WT, Dcir ${ }^{-1-}: \mathrm{n}=9$ each). ${ }^{*} P<0.05$, ${ }^{* *} P<0.01$ and ${ }^{* * *} P<0.005$ vs. WT mice.

mice at 7 days after immunization, whereas $\mathrm{CD} 11 \mathrm{c}^{+} \mathrm{DCs}$ were not (Figs. 5A and B). In spinal cord, the intensity of activation/maturation markers such as MHC class II, CD40, CD80, CD86, or OX40L on CD11 c cells, however, was unchanged between WT and $\mathrm{Dcir}^{-/}$mice at day 20 (Fig. 6A). The intensity of these activation/ maturation markers was also similar in LN cells (Fig. 6B). Moreover, the proportions of Th17 cells and Th1 cells, which are considered to be important for the development of EAE [14, 23, 44], in LNs were similar between WT and $\mathrm{Dcir}^{-/}$mice (Figs. 7A and B). Thus, these results demonstrate that cell infiltration into the spinal cord is greatly enhanced in $\mathrm{Dcir}^{-/}$mice, resulting in the exacerbation of EAE.

$M O G_{35-55}$-specific lymphocyte proliferative response is enhanced in Dcir-- mice

We next examined the proliferative response to $\mathrm{MOG}_{35-55}$ of lymphocytes from mice immunized with $\mathrm{MOG}_{35-55}$ and CFA plus pertussis toxin. Lymphocytes were collected from the draining LNs of WT and $\mathrm{Dcir}^{-/}$ mice at 7 days after immunization. We found that the proliferation of $\mathrm{DCir}^{-/}$lymphocytes was significantly enhanced than that of WT mice (Fig. 8). These results suggest that immunization efficiency is enhanced in $\mathrm{Dcir}^{-/}$mice. 

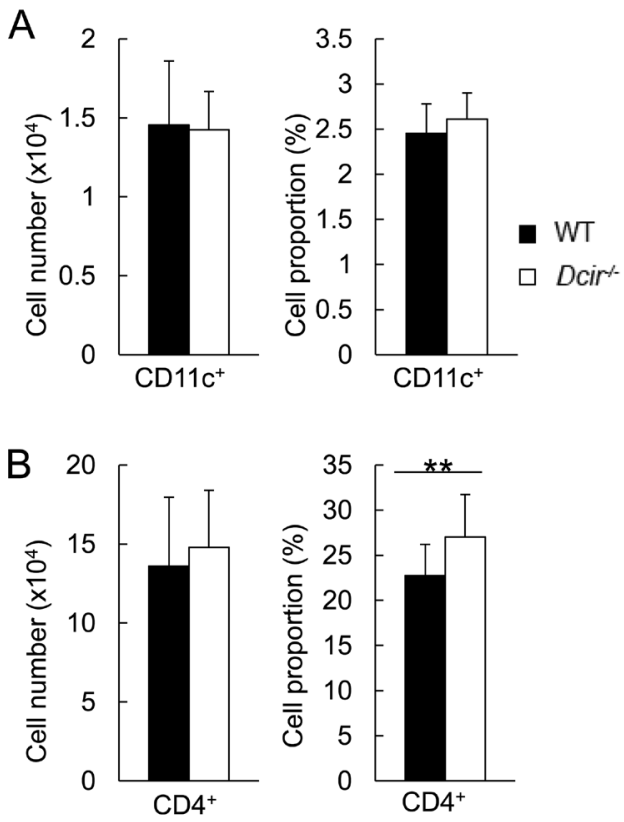

Fig. 5. $\mathrm{CD}^{+}$cells are increased in draining lymph nodes (LNs) of $\mathrm{Dcir}^{-1-}$ mice after $\mathrm{MOG}_{35-55}$ and CFA immunization. At day 7 after immunization, single cell suspensions were prepared from the LNs. Cells were analyzed by flow cytometry after staining with antibodies against antigens. The cell numbers and proportion of $\mathrm{CD} 11 \mathrm{c}^{+}$and $\mathrm{CD} 4^{+}$ cells were shown in (A) and (B) (WT, Dcir ${ }^{-1-}$ n=15 each). The data are expressed as means $+\mathrm{SD}$, and are combined results of three independent experiments. ${ }^{* *} P<0.01$ vs. WT mice.

\section{Discussion}

In this report, we showed that the development of EAE was significantly exacerbated in $\mathrm{Dcir}^{-/}$mice. The EAE score was significantly increased in $\mathrm{Dcir}^{-/-}$mice, indicating that DCIR is an important regulator of the disease. Because autoantibodies play an important role in the development of autoimmune diseases such as rheumatoid arthritis $[4,17,22,36]$ and MS [16, 26, 29], $\mathrm{MOG}_{35-55}$-specific Ig production was examined in EAE-induced mice. However, we found that serum levels of $\mathrm{MOG}_{35-55}$-specific antibodies of the $\operatorname{IgM}, \operatorname{IgG} 1, \operatorname{IgG} 2 \mathrm{a}$, and $\operatorname{IgG} 2 \mathrm{~b}$ subclasses were similar in $\mathrm{Dcir}^{-/}$mice and WT mice. Consistent with these results, we previously reported that serum levels of $\mathrm{MOG}_{35-55}$-specific Ig are not correlated with the development of EAE [20]. Furthermore, it was reported that autoantibody levels are not always proportional to EAE disease scores [18]. These results suggest that antibody-mediated humoral immune responses are dispensable for the development of EAE.

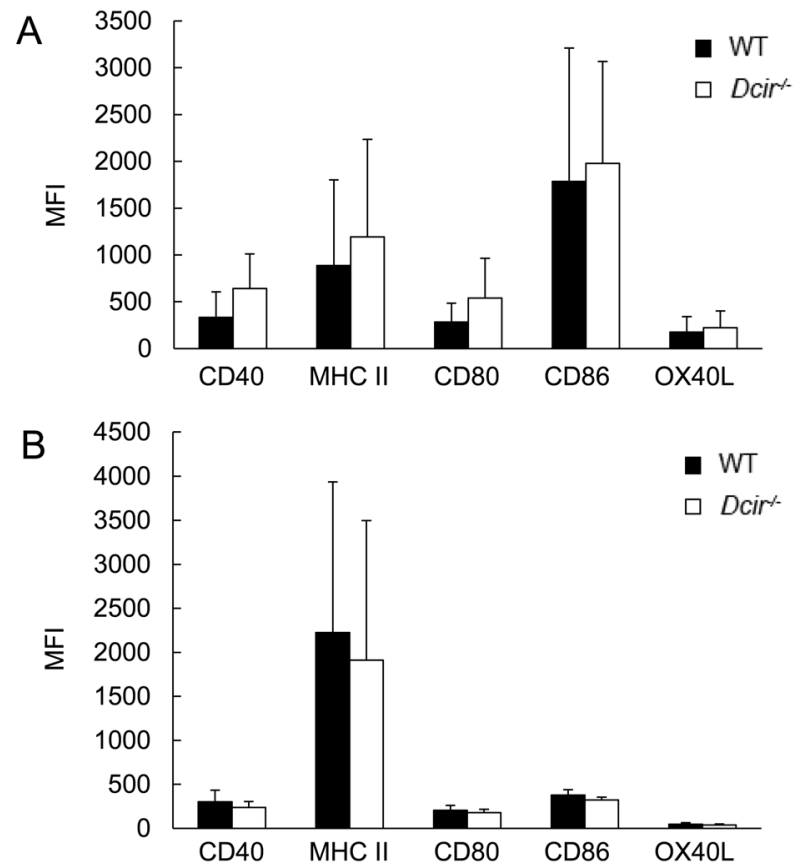

Fig. 6. The expression of activation markers on $\mathrm{CD} 11 \mathrm{c}^{+}$cells is similar between WT and cir $^{-1-}$ mice. (A, B) Single cell suspensions were prepared from spinal cords (A) and lymph nodes (LNs) (B) at day 20 after $\mathrm{MOG}_{35-55}$ and CFA immunization (WT: $\mathrm{n}=10, \mathrm{Dcir}^{-1-}: \mathrm{n}=9$ ). Cells were analyzed by flow cytometry after staining with antibodies against indicated antigens. The data are expressed as means $+\mathrm{SD}$, and are combined results of two independent experiments.

On the other hand, we found that infiltration of DCs and $\mathrm{CD}^{+} \mathrm{T}$ cells into the spinal cord was significantly increased in $\mathrm{Dcir}^{-/}$mice, suggesting $\mathrm{CD}^{+} \mathrm{T}$ cell-mediated cellular immune responses are important for the development of EAE.

DCs play a central role in regulating the acquired immune system $[6,42]$. Activation of T cells against pathogens and tolerance induction of autoreactive $\mathrm{T}$ cells are tightly controlled by DCs. If this regulation fails, T cells incorrectly recognize self-antigens and develop autoimmunity. DCs are also one of key modulators of encephalitogenic T cells, as shown in human MS and murine EAE [6]. During the development of EAE, peripheral DCs are sufficient to present antigens to prime myelinreactive $\mathrm{T}$ cells and initiate disease development $[8,15,30]$. We found that recall $\mathrm{T}$ cell proliferative response against $\mathrm{MOG}_{35-55}$ antigen was significantly augmented in T cells from $\mathrm{Dcir}^{-/}$mice, indicating that $\mathrm{T}$ cell priming is facilitated in $\mathrm{Dcir}^{-/}$mice.

It was reported that pathogenic Th17 cells, which is 


\section{A Gated on 7AAD-CD4 ${ }^{+}$CD8-}
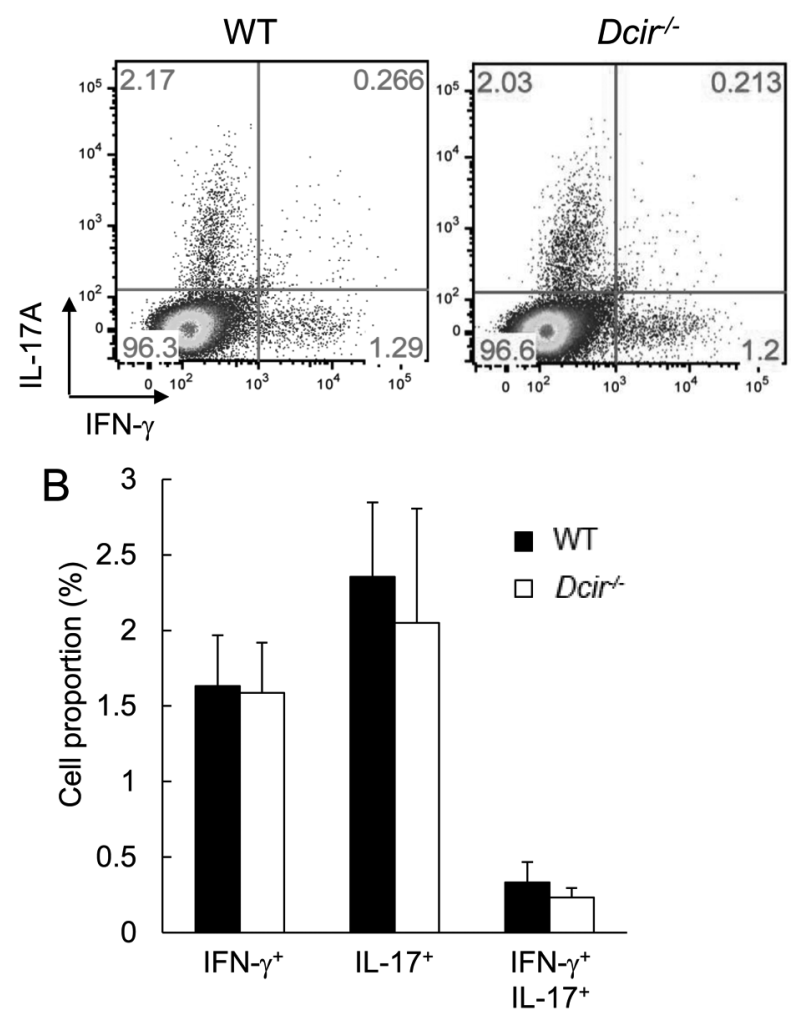

Fig. 7. Cytokine expression in $\mathrm{LN} \mathrm{CD} 4^{+} \mathrm{T}$ cells is similar between WT and $\mathrm{Dcir}^{-1-}$ mice. (A, B) Single cell suspensions were prepared from LNs at day 20 after $\mathrm{MOG}_{35-55}$ and CFA immunization, and after PMA/ionomycin stimulation, cells were stained with antibodies against indicated antigens and analyzed by flow cytometry (A). The proportion of IFN- $\gamma^{+}$, IL- $17^{+}$and IFN- $\gamma^{+}$IL- $17^{+} \mathrm{CD} 4^{+}$cells are shown in (B) (WT, Dcir ${ }^{-1-}: \mathrm{n}=8$ each). The data are expressed as means $+\mathrm{SD}$, and are combined results of two independent experiments.

important for the development of EAE, secrete GM-CSF, promoting accumulation of inflammatory macrophages into the CNS and activating DCs to induce IL-23 production. The secreted IL-23 in turn promotes Th17 cell differentiation, forming an amplification loop [5, 9]. We have previously shown that DCIR negatively regulates DC differentiation and proliferation by suppressing GMCSF receptor signaling through the ITIM in this molecule [11]. Indeed, we found that the CD11 $\mathrm{c}^{+} \mathrm{DC}$ number was significantly increased in the inflamed spinal cord and LNs of $\mathrm{Dcir}^{-1-}$ mice. However, the expression of CD80, CD86 and MHC class II molecules on CD11 $\mathrm{c}^{+}$DCs was normal in $\mathrm{Dcir}^{-/}$mice, indicating that DCIR may not be involved in the maturation/activation of DCs. The ex-

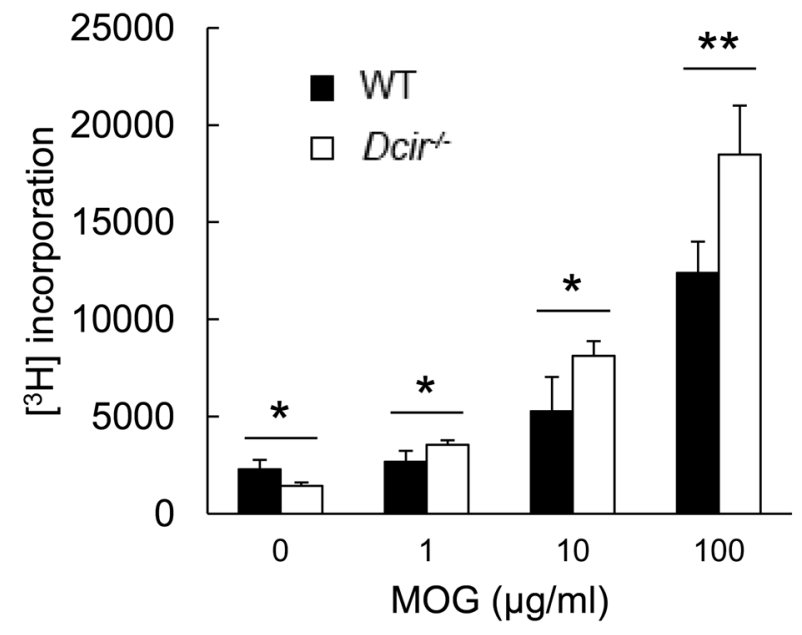

Fig. 8. T cell recall proliferative response against $\mathrm{MOG}_{35-55}$ peptide is enhanced in lymphocytes from $\mathrm{Dcir}^{-/}$mice. LN cells were harvested from mice $(n=6)$ at day 7 after immunization with $\mathrm{MOG}_{35-55}$, CFA, and pertussis toxin. Pooled cells were incubated in the presence or absence of $\mathrm{MOG}_{35-55}$ peptide for 3 days. $\left[{ }^{3} \mathrm{H}\right] \mathrm{TdR}$ was incorporated over the last $6 \mathrm{hr}$, and the incorporation of $\left[{ }^{3} \mathrm{H}\right]$ into acid insoluble fraction was measured. Data are presented as means $+\mathrm{SD}$, and are representative of two independent experiments. ${ }^{*} P<0.05$ and ${ }^{* *} P<0.01$ vs. WT mice.

pression of CD40 and OX40L, other activation markers, was also normal in these mice. Although we could not detect preferential expansion of Th17 cells in LNs (Fig. 7) nor increased production of IL-17 and IL-23 (data not shown), total $\mathrm{CD} 4^{+}$cells in the spinal cord and LNs were significantly increased in these $\mathrm{Dcir}^{-1}$ mice. Accordingly, total Th17 cell number in the spinal cord and draining LNs should be increased in these mice to promote inflammation after immunization with MOG peptides (Fig. 4). Therefore, these observations suggest that excess antigen presentation due to increased DC number which is caused by the hyper-responsiveness of DCs to GM-CSF, but not activation status of DCs, is responsible for the enhanced differentiation/proliferation of $\mathrm{T}$ cells after immunization with $\mathrm{MOG}_{35-55}$.

MS is an inflammatory disease in the central nervous system associated with demyelination of nerve cells, axonal loss/damage and gliosis. There is several MS types in terms of the clinical course; relapsing-remitting MS, secondary progressive MS (the late stage of relapsing-remitting MS) and primary progressive MS. Its clinical signs differ depending on the inflammation sites; the most common manifestations are somatosensory, pyramidal-motor and visual manifestations. Similar neu- 
roinflammatory disorder called EAE is induced experimentally in animals by injecting myelin antigens. Symptomes of EAE differ depending on the experimental conditions including the animals and the induction methods. C57BL/6 mice immunized with $\mathrm{MOG}_{35-55}$ in CFA with a booster injection at 7 days after the first immunization show the symptoms resembling secondary progressive MS with a gradual neurological deterioration. EAE clinical signs are scored as paralysis of their tail and extremities $[13,38,40]$. Tissue injury in both MS and EAE could be seen in the white matter of CNS $[13,14]$. EAE was induced in $\mathrm{Dcir}^{-/}$mice similarly as in C57BL/6 WT mice, but infiltration of leukocytes into the spinal cord was much enhanced and the histopathology was severer than that of WT, although the infiltrating cell population was similar to that of WT.

Taken together, these observations clearly show that DCIR is important not only in the development of autoimmune arthritis but also in the development of EAE, suggesting that DC regulation mediated by DCIR is generally important for the development of autoimmune diseases. Thus, targeting DCIR to harness DC differentiation/proliferation is one of important strategies to prevent or limit autoimmune diseases, and small compounds which can activate DCIR or agonistic antibodies should be good candidates to treat autoimmune diseases. Moreover, because DCIR also regulates other signals, such as toll-like receptor signals [32, 33], and is expressed in cells other than DCs, such as macrophages [2], targeting DCIR may also be useful to control broader range of diseases including infectious diseases. Our studies also indicate that $\mathrm{Dcir}^{-/-}$mice are useful for the studies of autoimmune diseases, because autoimmunity is easily induced in these mice. Clearly, further investigation is needed to elucidate the functions and roles of DCIR under healthy conditions and in diseases.

\section{Acknowledgements}

We thank to all members of our laboratory for their kind cooperation, discussion and animal care. We thank to Prof. Masahira Hattori for valuable discussion, Dr. Shinobu Ohmi for $\mathrm{MOG}_{35-55}$ synthesis, and Dr. Shinobu Saijo for critical reading of the manuscript. This work was supported by the Science and Technology Research Promotion Program for Agriculture, Forestry, Fisheries and Food Industry (to Y. I.), CREST from Japan Science and Technology Agency (Y. I.), and Grants-in Aid from the Ministry of Education, Culture, Sports, Science and Technology of Japan (Y. I.). A. S. is supported by the Global COE Program "Deciphering Biosphere from Genome Big Bang”, MEXT, Japan.

\section{References}

1. Bailey, S.L., Schreiner, B., McMahon, E.J., and Miller, S.D. 2007. CNS myeloid DCs presenting endogenous myelin peptides 'preferentially' polarize $\mathrm{CD}^{+} \mathrm{T}_{(\mathrm{H})}-17$ cells in relapsing EAE. Nat. Immunol. 8: 172-180. [Medline] [CrossRef]

2. Bates, E.E., Fournier, N., Garcia, E., Valladeau, J., Durand, I., Pin, J.J., Zurawski, S.M., Patel, S., Abrams, J.S., Lebecque, S., Garrone, P., and Saeland, S. 1999. APCs express DCIR, a novel C-type lectin surface receptor containing an immunoreceptor tyrosine-based inhibitory motif. J. Іттиnol. 163: 1973-1983. [Medline]

3. Billiau, A., Heremans, H., Vandekerckhove, F., Dijkmans, R., Sobis, H., Meulepas, E., and Carton, H. 1988. Enhancement of experimental allergic encephalomyelitis in mice by antibodies against IFN-gamma. J. Immunol. 140: 15061510. [Medline]

4. Bläss, S., Haferkamp, C., Specker, C., Schwochau, M., Schneider, M., and Schneider, E.M. 1997. Rheumatoid arthritis: autoreactive $\mathrm{T}$ cells recognising a novel $68 \mathrm{k}$ autoantigen. Ann. Rheum. Dis. 56: 317-322. [Medline] [CrossRef]

5. Codarri, L., Gyülvészi, G., Tosevski, V., Hesske, L., Fontana, A., Magnenat, L., Suter, T., and Becher, B. 2011. ROR $\gamma \mathrm{t}$ drives production of the cytokine GM-CSF in helper T cells, which is essential for the effector phase of autoimmune neuroinflammation. Nat. Immunol. 12: 560-567. [Medline] [CrossRef]

6. Comabella, M., Montalban, X., Münz, C., and Lünemann, J.D. 2010. Targeting dendritic cells to treat multiple sclerosis. Nat. Rev. Neurol. 6: 499-507. [Medline]

7. Compston, A. and Coles, A. 2008. Multiple sclerosis. Lancet 372: 1502-1517. [Medline] [CrossRef]

8. Dittel, B.N., Visintin, I., Merchant, R.M., and Janeway, C.A. Jr. 1999. Presentation of the self antigen myelin basic protein by dendritic cells leads to experimental autoimmune encephalomyelitis. J. Immunol. 163: 32-39. [Medline]

9. El-Behi, M., Ciric, B., Dai, H., Yan, Y., Cullimore, M., Safavi, F., Zhang, G.X., Dittel, B.N., and Rostami, A. 2011. The encephalitogenicity of $\mathrm{T}_{(\mathrm{H})} 17$ cells is dependent on IL1- and IL-23-induced production of the cytokine GM-CSF. Nat. Immunol. 12: 568-575. [Medline] [CrossRef]

10. Fujikado, N., Saijo, S., and Iwakura, Y. 2006. Identification of arthritis-related gene clusters by microarray analysis of two independent mouse models for rheumatoid arthritis. Arthritis Res. Ther. 8: R100. [Medline] [CrossRef]

11. Fujikado, N., Saijo, S., Yonezawa, T., Shimamori, K., Ishii, A., Sugai, S., Kotaki, H., Sudo, K., Nose, M., and Iwakura, Y. 2008. Dcir deficiency causes development of autoimmune diseases in mice due to excess expansion of dendritic cells. Nat. Med. 14: 176-180. [Medline] [CrossRef]

12. Furlan, R., Brambilla, E., Ruffini, F., Poliani, P.L., Berga- 
mi, A., Marconi, P.C., Franciotta, D.M., Penna, G., Comi, G., Adorini, L., and Martino, G. 2001. Intrathecal delivery of IFN-gamma protects C57BL/6 mice from chronic-progressive experimental autoimmune encephalomyelitis by increasing apoptosis of central nervous system-infiltrating lymphocytes. J. Immunol. 167: 1821-1829. [Medline] [CrossRef]

13. Gold, R., Linington, C., and Lassmann, H. 2006. Understanding pathogenesis and therapy of multiple sclerosis via animal models: 70 years of merits and culprits in experimental autoimmune encephalomyelitis research. Brain 129: 1953-1971. [Medline] [CrossRef]

14. Goverman, J. 2009. Autoimmune T cell responses in the central nervous system. Nat. Rev. Immunol. 9: 393-407. [Medline] [CrossRef]

15. Greter, M., Heppner, F.L., Lemos, M.P., Odermatt, B.M., Goebels, N., Laufer, T., Noelle, R.J., and Becher, B. 2005. Dendritic cells permit immune invasion of the CNS in an animal model of multiple sclerosis. Nat. Med. 11: 328-334. [Medline] [CrossRef]

16. Hauser, S.L., Waubant, E., Arnold, D.L., Vollmer, T., Antel, J., Fox, R.J., Bar-Or, A., Panzara, M., Sarkar, N., Agarwal, S., Langer-Gould, A., Smith, C.H., and HERMES Trial Group 2008. B-cell depletion with rituximab in relapsingremitting multiple sclerosis. N. Engl. J. Med. 358: 676-688. [Medline] [CrossRef]

17. Hoet, R.M., Boerbooms, A.M., Arends, M., Ruiter, D.J., and van Venrooij, W.J. 1991. Antiperinuclear factor, a marker autoantibody for rheumatoid arthritis: colocalisation of the perinuclear factor and profilaggrin. Ann. Rheum. Dis. 50: 611-618. [Medline] [CrossRef]

18. Huang, D.R., Wang, J., Kivisakk, P., Rollins, B.J., and Ransohoff, R.M. 2001. Absence of monocyte chemoattractant protein 1 in mice leads to decreased local macrophage recruitment and antigen-specific $\mathrm{T}$ helper cell type 1 immune response in experimental autoimmune encephalomyelitis. $J$. Exp. Med. 193: 713-726. [Medline] [CrossRef]

19. Kapsenberg, M.L. 2003. Dendritic-cell control of pathogendriven T-cell polarization. Nat. Rev. Immunol. 3: 984-993. [Medline] [CrossRef]

20. Komiyama, Y., Nakae, S., Matsuki, T., Nambu, A., Ishigame, H., Kakuta, S., Sudo, K., and Iwakura, Y. 2006. IL-17 plays an important role in the development of experimental autoimmune encephalomyelitis. J. Immunol. 177: 566-573. [Medline] [CrossRef]

21. Kroenke, M.A., Carlson, T.J., Andjelkovic, A.V., and Segal, B.M. 2008. IL-12- and IL-23-modulated T cells induce distinct types of EAE based on histology, CNS chemokine profile, and response to cytokine inhibition. J. Exp. Med. 205: 1535-1541. [Medline] [CrossRef]

22. Lackner, K.J., Schlosser, U., Lang, B., and Schmitz, G. 1998. Autoantibodies against human calpastatin in rheumatoid arthritis: epitope mapping and analysis of patient sera. $\mathrm{Br}$. $J$. Rheumatol. 37: 1164-1171. [Medline] [CrossRef]

23. Lee, E., Chanamara, S., Pleasure, D., and Soulika, A.M. 2012. IFN-gamma signaling in the central nervous system controls the course of experimental autoimmune encephalomyelitis independently of the localization and composition of inflammatory foci. J. Neuroinflammation 9: 7. [Medline] [CrossRef]

24. Litzenburger, T., Fässler, R., Bauer, J., Lassmann, H., Linington, C., Wekerle, H., and Iglesias, A. 1998. B lymphocytes producing demyelinating autoantibodies: development and function in gene-targeted transgenic mice. J. Exp. Med. 188: 169-180. [Medline] [CrossRef]

25. Liu, J., Marino, M.W., Wong, G., Grail, D., Dunn, A., Bettadapura, J., Slavin, A.J., Old, L., and Bernard, C.C. 1998. TNF is a potent anti-inflammatory cytokine in autoimmunemediated demyelination. Nat. Med. 4: 78-83. [Medline] [CrossRef]

26. Lund, F.E. and Randall, T.D. 2010. Effector and regulatory B cells: modulators of $\mathrm{CD}^{+} \mathrm{T}$ cell immunity. Nat. Rev. Immunol. 10: 236-247. [Medline] [CrossRef]

27. Marta, M. 2009. Toll-like receptors in multiple sclerosis mouse experimental models. Ann. N. Y. Acad. Sci. 1173: 458-462. [Medline] [CrossRef]

28. Matsuki, T., Nakae, S., Sudo, K., Horai, R., and Iwakura, Y. 2006. Abnormal T cell activation caused by the imbalance of the IL-1/IL-1R antagonist system is responsible for the development of experimental autoimmune encephalomyelitis. Int. Immunol. 18: 399-407. [Medline] [CrossRef]

29. Matsushita, T., Yanaba, K., Bouaziz, J.D., Fujimoto, M., and Tedder, T.F. 2008. Regulatory B cells inhibit EAE initiation in mice while other B cells promote disease progression. $J$. Clin. Invest. 118: 3420-3430. [Medline]

30. McMahon, E.J., Bailey, S.L., Castenada, C.V., Waldner, H., and Miller, S.D. 2005. Epitope spreading initiates in the CNS in two mouse models of multiple sclerosis. Nat. Med. 11: 335-339. [Medline] [CrossRef]

31. Medzhitov, R. 2007. Recognition of microorganisms and activation of the immune response. Nature 449: 819-826. [Medline] [CrossRef]

32. Meyer-Wentrup, F., Benitez-Ribas, D., Tacken, P.J., Punt, C.J., Figdor, C.G., de Vries, I.J., and Adema, G.J. 2008. Targeting DCIR on human plasmacytoid dendritic cells results in antigen presentation and inhibits IFN- $\alpha$ production. Blood 111: 4245-4253. [Medline] [CrossRef]

33. Meyer-Wentrup, F., Cambi, A., Joosten, B., Looman, M.W., de Vries, I.J., Figdor, C.G., and Adema, G.J. 2009. DCIR is endocytosed into human dendritic cells and inhibits TLR8mediated cytokine production. J. Leukoc. Biol. 85: 518-525. [Medline] [CrossRef]

34. Mills, K.H. 2011. TLR-dependent T cell activation in autoimmunity. Nat. Rev. Immunol. 11: 807-822. [Medline]

35. Nakae, S., Asano, M., Horai, R., Sakaguchi, N., and Iwakura, Y. 2001. IL-1 enhances T cell-dependent antibody production through induction of CD40 ligand and OX40 on T cells. J. Immunol. 167: 90-97. [Medline] [CrossRef]

36. Nienhuis, R.L. and Mandema, E. 1964. A new serum factor in patients with rheumatoid arthritis; the antiperinuclear factor. Ann. Rheum. Dis. 23: 302-305. [Medline] [CrossRef]

37. Okuda, Y., Okuda, M., and Bernard, C.C. 2002. The suppression of $\mathrm{T}$ cell apoptosis influences the severity of disease during the chronic phase but not the recovery from the acute phase of experimental autoimmune encephalomyelitis in mice. J. Neuroimmunol. 131: 115-125. [Medline] [Cross- 
Ref]

38. Rao, P. and Segal, B.M. 2004. Experimental autoimmune encephalomyelitis. Methods Mol. Med. 102: 363-375. [Medline]

39. Stromnes, I.M., Cerretti, L.M., Liggitt, D., Harris, R.A., and Goverman, J.M. 2008. Differential regulation of central nervous system autoimmunity by $\mathrm{T}_{(\mathrm{H})} 1$ and $\mathrm{T}_{(\mathrm{H})} 17$ cells. Nat. Med. 14: 337-342. [Medline] [CrossRef]

40. Stromnes, I.M. and Goverman, J.M. 2006. Active induction of experimental allergic encephalomyelitis. Nat. Protoc. 1: 1810-1819. [Medline] [CrossRef]

41. Thakker, P., Leach, M.W., Kuang, W., Benoit, S.E., Leonard, J.P., and Marusic, S. 2007. IL-23 is critical in the induction but not in the effector phase of experimental autoimmune encephalomyelitis. J. Immunol. 178: 2589-2598. [Medline] [CrossRef]

42. Ueno, H., Klechevsky, E., Morita, R., Aspord, C., Cao, T., Matsui, T., Di Pucchio, T., Connolly, J., Fay, J.W., Pascual, V., Palucka, A.K., and Banchereau, J. 2007. Dendritic cell subsets in health and disease. Immunol. Rev. 219: 118-142. [Medline] [CrossRef]

43. Voorthuis, J.A., Uitdehaag, B.M., De Groot, C.J., Goede,
P.H., van der Meide, P.H., and Dijkstra, C.D. 1990. Suppression of experimental allergic encephalomyelitis by intraventricular administration of interferon-gamma in Lewis rats. Clin. Exp. Immunol. 81: 183-188. [Medline] [CrossRef]

44. Willenborg, D.O., Fordham, S., Bernard, C.C., Cowden, W.B., and Ramshaw, I.A. 1996. IFN- $\gamma$ plays a critical downregulatory role in the induction and effector phase of myelin oligodendrocyte glycoprotein-induced autoimmune encephalomyelitis. J. Immunol. 157: 3223-3227. [Medline]

45. Yonekawa, A., Saijo, S., Hoshino, Y., Miyake, Y., Ishikawa, E., Suzukawa, M., Inoue, H., Tanaka, M., Yoneyama, M., Oh-Hora, M., Akashi, K., and Yamasaki, S. 2014. Dectin-2 is a direct receptor for mannose-capped lipoarabinomannan of mycobacteria. Immunity. 41: 402-413. [Medline] [CrossRef]

46. Zhou, D., Srivastava, R., Nessler, S., Grummel, V., Sommer, N., Brück, W., Hartung, H.P., Stadelmann, C., and Hemmer, B. 2006. Identification of a pathogenic antibody response to native myelin oligodendrocyte glycoprotein in multiple sclerosis. Proc. Natl. Acad. Sci. USA 103: 19057-19062. [Medline] [CrossRef] 